\title{
Analysis of Physical Education Classes in a Brazilian Public School
}

\author{
Lisiane Teixeira de Armas Carvalho \\ Elementary School teacher, \\ Rio Grande do Sul, Brazil \\ Bento Selau \\ Professor at UNIPAMPA' Graduate Program in Education (PPGEdu), \\ Rio Grande do Sul, Brazil

\section{Lúcio Jorge Hammes} \\ Professor at UNIPAMPA' Graduate Program in Education (PPGEdu), \\ Rio Grande do Sul, Brazil
}

\begin{abstract}
This study aimed at analyzing Physical Education classes in the first years of an Elementary School located in an outlying ghetto in a Brazilian city. The methodological proposal was relational psychomotricity, intended for evaluating whether it enables the development of students imitative activity. Regarding methodology, it was a pedagogical intervention whose data collection tools were observation and a focus group. Its subjects were children attending the first years in Elementary School. Results showed that the proposal of relational psychomotricity was appropriate to the pedagogical work carried out by the reference teacher with children attending these classes. Despite teacher interventions, imitation emerged in free activities throughout the play time, enabling an increase in the imitative activity.
\end{abstract}

Keywords: Cultural-Historical Psychology; Physical Education; Imitation; Brazil; reference teacher.

\section{INTRODUCTION}

The law that established the National Education Guidelines in Brazil, no. 9.394, article 26, 3rd $\S$, states that "[p]hysical education, integrated to the pedagogical proposal of the school, is a mandatory component of the basic education curriculum" (BRASIL, 2014, p. 19). According to Resolution no. 7, issued on December 14th, 2010, which established the National Curriculum Guidelines for the 9-year Elementary School (BRASIL, 2010), Physical Education (PE) is a mandatory component.

In the first years of Elementary education in Brazil, either a pedagogue or a reference teacher (not necessarily a PE teacher) may be in charge of this curriculum component. The term "reference teacher" is used for describing "the professional who students spend more time with at school" (BRASIL, 2010, p. 9).

The fact that there is no teacher who has graduated in PE working in the first years of Elementary education in some schools does not devalue the pedagogical work. Regardless of their graduation, teachers who develop this curriculum component should, theoretically, know what they are doing. Furini and Selau (2010) have defended not only teachers' development 
but also the need they have to enchant themselves with their practices. Both are features of a teacher who can exercise teaching activities:

What determines teaching quality, in any level, is, on one hand, the quality of the education teachers construct along their academic life and, on the other hand, doing what one likes. I have said that because there are teachers - in all teaching levels who state that teaching classes is a cause of distress. However, they study little. They do not realize that we do not work merely to make a living but also to find existential meaning. The ones who do what they like end up making the difference; it seems to be a general rule. [...] The fact that teachers have graduated in PE does not mean that they are more capable of carrying out the task (Furini \& Selau, 2010, p. 116).

It means that pedagogues may teach PE classes, provided that they are theoretically prepared. Teachers must have knowledge of the PE area, the objectives and specificities of the curriculum component.

PE, in the first years of Elementary School, has been taught by reference teachers in many institutions but, unfortunately, it does not necessarily have a methodology which was previously defined by the Pedagogical Political Project (PPP). Classes are often based on themes and carried out either as projects or games and playful activities that aim at developing learning related to the objectives of other curriculum components. Therefore, this study proposes to introduce a PE teaching methodology, i.e., relational psychomotricity, which may be used by reference teachers. It is based on the results of a research which aimed at analyzing such classes in a school located in an outlying ghetto. The methodological proposal, that is relational psychomotricity, was evaluated to check whether it enables the development of students' imitative activity, in the light of L. S. Vygotski's Cultural-Historical Psychology.

Several investigations into relational psychomotricity as a proposal for PE teaching methodology in pre-school and Elementary schools have been carried out in Brazil (Falkenbach, 2002; Negrine, 2002) and in Spain (Negrine, 1993). Other studies have recently reinforced the idea of relational psychomotricity as a method of pedagogical work which is effective for bodywork with children in PE classes (Furini \& Selau, 2010; Oliveira \& Basegio, 2016).

This intervention-research resulted from pedagogues' need to think about the management of PE practices in primary education in a public school located in Jaguarão, RS, Brazil. In this institution, there was no methodological proposal for PE classes in the PPP before 2015. In this case, the project allowed many interpretations of how to proceed pedagogically in the classes and often gave the curriculum component a merely recreational purpose.

Subjects of this study were first graders from low-income families. There were sixteen sixyears-old children, five boys and eleven girls. The research was made with the same group of children. Therefore, the school needs to adapt several materials, such as broom handles (which become batons), sock balls (which turn into toy balls) and PET bottles (which turn into bowling pins) to be used in PE classes. In this case, teachers must be attentive to the possibility of using these materials in PE classes.

To reach this proposal, two investigation movements were needed: firstly, class structure evaluation (Fonseca, 2015); secondly, relevance of learning in terms of imitation (Vygotski, 1993). Such issues are discussed by this paper, after the Literature review and Methodological procedures. 


\section{LITERATURE REVIEW}

Reference teachers, who are competent to plan, carry out and evaluate PE activities in the early-years education in Elementary School, in their pedagogical task, deal with several elements, such as games and its peculiarities, imitation and relations among peers, which require their attention since they are part of children's activities. One of these aspects is imitation.

This theme was analyzed by Vygotski (1993), in his studies of the development of scientific concepts of childhood. The author states that the issue of imitation, from the perspective of the old psychology and common sense, used to be considered a merely mechanical activity. However, this view does not show a child's capacity and Vygotski (1993) highlights the fact that this conception is wrong. He believes that the possibility of imitating needs some possibility of proceeding from what one knows how to do to something other does not know. Imitation reveals an important aspect when children play games: collaboration. Vygotski (1993) points out that, when children collaborate, they can do more than they do alone, within certain limits determined by their developmental stage and intellectual potentialities. Children become stronger and smarter when they work in collaboration than independently.

Even though animals are capable of imitating, it does not make them advance in the field of their intellectual potentialities, since the learning process does not reveal any consciousness. However, imitation, as a result of collaboration, is fundamental to children's development. Therefore, the core moment in learning psychology is that collaboration may rise to a higher level of intellectual possibilities, i.e., children may proceed from what they can do to what they cannot do by imitation:

This allows us to introduce an addendum to what we said earlier concerning collaborative work and imitation. We said that in collaboration the child can always do more than he can independently. We must add the stipulation that he cannot do infinitely more. What collaboration contributes to the child's performance is restricted to limits which are determined by the state of his development and his intellectual potential. In collaboration the child turns out to be stronger and more able than in independent work, he advances in terms of work. He advances in terms of the level of intellectual difficulties he is able to face. However, there always exists a definite, strictly lawful distance that determines the differential between his performance in independent and collaborative work (Vygotski, 1993, p. 240).

The concept of Zone of Proximal Development (ZPD) is related to these aspects. Imitation, in the broad sense, is the main form in which influence of learning on development is carried out. In school, children do not learn what they can do alone - their actual developmental level -; they learn what they do not know yet and what becomes accessible when they work in collaboration with teachers and follow their guidelines. The key to learning is precisely the fact that the child learns the new. Therefore, the ZPD, which determines this field of transitions which are accessible to children, is the one that represents the most decisive moment in the relation between learning and developing. Children will do alone tomorrow what they are capable of doing with someone's help today. Learning can occur where imitation occurs.

Baquero (1998) highlights some ZPD complements. He states that not all interaction with more experienced people generates development. According to Baquero (1998), to enable learning to lead to development, it must operate on "the conquests of development which are still being acquired" (Baquero, 1998, p. 99). Comprehending ZPD means that the role of imitation in learning must be re-evaluated. In the light of Damiani (2000): 
Imitation becomes an essential activity in learning. It enables means for the development of something new to be acquired (...), a process that involves much more than mere copy, since it implies internal reconstruction of external operations, in which the subject plays an active role (Damiani, 2000, p. 3).

Activities that children performs either with the guidance of other more experienced person or by imitation are soon carried out by them with no need of reference at all. According to Fernandes (2007),

(...) only what is in the zone of intellectual potentialities can be imitated. (...) the demonstration of how it is done leads to the solution. However, if children are not yet able to dominate more sophisticate techniques, demonstration does not make thinking advance, i. e., in order to imitate, there must be some possibility of going beyond what one knows how to do towards what one cannot do yet. When children work in collaboration, they can always do more than they do alone (Fernandes, 2007, p. 5).

On the word of Vygotski (1993), imitation is an activity that promotes learning because it enables children to go beyond the limits of their own capacities. He considers imitation a process that makes learning and, consequently, development, easier.

\section{METHODOLOGICAL PROCEDURES}

This study takes into account the methodological approach of interventionist research (Laitinen, Sannino \& Engeström, 2016; Daniels, 2016; Stetsenko, 2016; Bonnefond et al., 2016; González Rey, Goulart \& Bezerra, 2016), do in pedagogical practice (Damiani et al., 2013). The introduction of the methodological proposal must basically take into account the description of the teaching procedure and how data is collected.

The proposal for PE classes was based on the methodology of relational psychomotricity. According to Negrine (2002), classes have three moments in this proposal: entrance, development and exit.

Entrance is the initial moment when the teacher asks the children to form a circle, describes the class, encourages them to talk about what they want to play, stimulates them to take part in the playful activities and then explains the organization of the environment. The right to speak must be respected and the teacher must assure this right, besides informing what can be done in the session - which is free, provided that previous common arrangements are respected.

Development refers to the class itself, that is to say, the moment when playful activities are carried out and the teacher interventions promote progress from one activity to another, in order to enable children's development and mediate conflicts. Play is free, to be precise, the child chooses the playful activity but should commit to arrangements that were agreed on at the first moment of the class - the entrance. The teacher pedagogical intervention must happen throughout all moments. It is not only restricted to the development but, in this study, the focus of the teaching practice concentrated on this moment. Playful activities that are not guided by the teacher make children "trigger thinking mechanisms all the time to execute technical or symbolic movements, to imitate their peers and to experience new situations" (Negrine, 2002, p. 152).

Exit, which is the closure, begins when the teacher announces that the class has finished and asks the children to help put class objects away and form a circle. It is fundamental because, at this moment, each child narrates the playful activities and the teacher points out suggestions for difficulties they faced. 
For evaluating this qualitative research, two data collection tools were used: observation and focus group. According to Lakatos \& Marconi (2010), observation is a technique in which senses are used for capturing certain aspects of reality and examine facts and phenomena which one wishes to study. Observations, which were carried out throughout the whole development process of PE classes, summed up eight hours in 16 classes. According to Gondim (2003), the focus group is an intermediate technique between participatory observation and in-depth interviews. Its analysis unit is the group itself. Every focus group was a space of sharing among children and the teacher. Total time was 5 hours and 20 minutes in 16 meetings. In this study, the focus group happened in the third moment of the classes, when the reference teacher asked children why they had developed certain playful activities and changed them, mainly when children's imitative activity was observed.

All care related to research ethics was taken: the necessary documentation to release the children to participate in the research was signed by the parents or responsible ones, according to the recommendations of the institutions involved.

In this study, data were analyzed by Discursive Textual Analysis, proposed by Moraes (2003). Emergent categories were: "Imitation" and "Evaluation of PE Classes", which are discussed below.

\section{RESULTS AND DISCUSSION}

Taking into account that "Imitation" - first category - is fundamental to children's learning and development, the following question is posed: does imitation emerge during children's play in relational psychomotricity classes? A class which the proposal for relational psychomotricity is applied, imitative activity was performed by all children in certain moments. These data are shown below:

Imitation was performed by some children to learn something another classmate had done. Some reports: children asked a classmate to carry out an activity so that they could imitate it (Observation 4); some traditional playful activities carried out by some children were based on imitation since a child led the group and decided that the others should imitate him while he moved around in a certain situation. In relational psychomotricity classes, imitation was often used for learning or showing how to use some material. In Observation 16: "some children helped others jump rope through imitation". In Focus Group 7, a boy reported that he tried to learn how to rotate a hula hoop around his waist and his arm by imitating a classmate. Imitation made some children discover new ways to use some material whereas others solved some problems, such as disjointed hoops (Observation 1).

Some children reported that imitation makes learning easier in PE classes and mentioned that they preferred "looking and imitating what they wanted to learn", because "sometimes, just the explanation is not enough" (Focus Group 7, boys and girls). On the same occasion, a boy said that he had tried to imitate one of the girls and, with her help, things got easier (Focus Group 9, boy). Some girls reported that they had learned a certain playful activity when they "tried to do what their classmates were doing" (Focus Group 9, girls). Other children said that they were doing better now because classmates were helping and showing how to do it (Focus Group 11, boys and girls). Others stated that they can do better when another child either explains or shows how to do it (Focus Group 13, boys and girls).

Imitation was used for improving activities that were carried out, either by testing possibilities or by finding the best way to execute them. In Observation 10, some children explained to their classmates how to throw a ball higher and how to coil a rope around a goalpost. In Observation 
5, some children tested the distance and strength needed to put objects on the goalpost in the soccer court.

Sometimes imitation was trigged from a movement that was performed by some children. Thus, some students were imitated either by classmates who played with them or by classmates who were playing farther away but imitated their movement. An example was a boy who threw his hula hoop up and tried to catch it in the air. He was imitated by another boy and, later, by two girls (Observation 1). Likewise, girls who played with their hula hoops were imitated by other children (Observation 2).

The development of some pretend play (Vigotski, 2008) was based on the imitation of another child, character or animal. These activities were carried out in several classes. When children spoke about activities in which they imitated animals, they said: "it is very nice to imitate animals' voices and the way they walk, just like my classmate did" (Focus Group 12, boys and girls).

Other playful activities were generated when the teacher attitude was imitated. For instance, in Observation 1, when the teacher kicked the sock ball back to the children, they realized that it was allowed to kick that ball and imitated her.

Imitation led to the beginning of certain playful activities. In a certain class (Focus Group 10, girl), a girl stated that "the one who cannot throw the hula hoop very far must either imitate or ask a classmate how to do it". Another girl said: "when I imitate I can do things properly, but when I cannot see anyone doing something, it is harder" (Focus Group 10, girl).

Regarding play, models that are initially imitated become the basis to carry new activities out and develop ideas and playful activities. The richer and the more assorted the models are, the higher the possibility of creating through imitation will be.

Imitation, throughout free activities in relational psychomotricity, was maximized as a result of the teacher interventions. Interaction among boys and girls occurred constantly in some classes due to the teacher intervention: "boys and girls started to interact after the teacher questioned them about gender division in the activities" (Observation 7). In several classes, the teacher suggested that students should use imitation either to learn or teach classmates. In the focus group, at the end of the class, the teacher and the children talked about the value of observation and imitation to learn, or rather, an action (Focus Group 15). In Focus Group 10, the teacher asked the girls about activities with ropes and hula hoops and about how they had taught their classmates who did not know how to use them. In Observation 9, the teacher asked the children with hula hoops to observe and imitate others to learn.

According to Furini \& Selau (2010), the fundamental principle of a teacher intervention in relational psychomotricity is mediation, usually to broaden the child's idea or to trigger initiative, thus, avoiding the need for commands throughout activities. Therefore, children were asked about their attitudes to guide them to find solutions for their problems and help them recognize negative behaviour towards their classmates. When the teacher stimulated children to play with classmates they did not use to play with, "she triggers learning situations through new model [imitation]" (Falkenbach, 2002, p. 45).

"Evaluation of PE Classes" - the second category - includes the possibilities offered by relational psychomotricity and the children's opinions about the classes. 
Relational psychomotricity allowed participant children to have some opportunities, such as changing activities and creating a new game, since they could explore the material and decide how to use it (Observations 1 and 9). Relational psychomotricity must enable exploration of the space and the material, besides promoting group activities and problem solving through playful activities (Falkenbach, 2002).

The comparison of opinions and the contact with objects that they do not use frequently were reported by the children (Focus Groups 2 and 4, boys and girls). These situations should be enhanced whenever possible. According to Falkenbach (2002, p. 77), this methodology is "a ludic-educational mean that enable children to express themselves through games and activities". The contact with new material supports the evolution of playful activities.

Body capacity was enhanced in every child as a result of the variety of activities carried out every class and the possibility of exploring materials and using the space, as highlighted by Observations 13 and 16. Therefore, this enhancement in body capacity happens due to learning that children acquire while playing and repeating activities regularly, progressively and playfully, rather than by performing a mere activity in a class.

When children evaluated PE classes in the light of relational psychomotricity, they showed interest and satisfaction towards the activities they had carried out in the intervention. Most children liked the PE classes from this methodological perspective. One girl said: "I prefer classes this way rather than when the teacher tells us what to do", another student emphasizes: "I like going to the playground, but I would like to keep having this classes" (Focus group 8, girls). Some boys reassured that "the playing was very nice" (Focus group 10, boys). In general, children reported that they enjoyed "the lessons, the materials and the talking after class" (Focus group 16, boys and girls). Although they don't have theoretical reference to evaluate the methodology used, children realized the value of these classes. These points to the need for a methodological change in the Physical Education classes developed at the institution where the research was carried out.

One of the contributions of Vygotski's theory to PE in schools is the principle that "listening and speaking moments help dialogue to develop and the group comprehension as a unit that takes part in a collective class. The sense of group should involve participants all the time (Falkenbach, 2002, p. 48). These moments, which happen in the ritual at the end of the class in this methodology, enable children to verbalize how they feel and learn to listen, thus, developing respect and care for the others. According to Negrine (2002, p. 213), every class ritual is a fundamental moment because "they help children acquire relevant references in their personal organization". The teacher and the children discussed issues that referred to differences in the ways the groups organized their activities, pre-established rules and the type of interaction between girls and boys. The teacher sometimes questioned the organization (Focus Group 3), the dynamics (Focus Group 4) and the rules (Observation 7) established by the children in the activities. It was also necessary to interfere in order to effect what the group had arranged (Observation 8) and guide the class dynamics (Observation 6). The teacher helped solve conflicts related to lack of leadership, some children's authoritarianism and disrespect for some group rules. For instance, in Focus Group 6, the teacher questioned the boys about the fact that they played when they chose a leader but refused to play when the leader belonged to another group. Besides, the teacher also asked them about the pre-established rules of the group.

Relational psychomotricity allowed the teacher to make interventions throughout the activity, even though the main idea was the use of free activities. The teacher carried out some 
interventions to make the use of some material easier (Observation 10), encourage the use of others and question how children used certain objects, such as puppets (Observation 11) and construction games (Observation 14). She also suggested activities to the girls who did not know how to use dice (Observation 9) and encouraged children to create new activities by questioning the organization (Focus Group 1), the choice of materials (Focus Groups 11, 13 and 14), the origin of the initial idea (Focus Group 2, 4 and 10) and other factors.

It is important to highlight some of the limits that the results of this research impose: The data collected do not allow the assertion that the imitations carried out by the children can be a trigger for development, as advocated by Vygotski (1993). The central problem of this finding is that the research time was restricted to a period of eight hours in a total of 16 classes. In order to establish such a relationship, it would be necessary to repeat the research method in later periods.

The expansion of the corporal capacities of each child, promoted by the variety of activities performed at each class, from the exploitation of the materials and available spaces, was perceived by the teacher, but had no basis for comparison (what he could and what he could not do). Therefore, this result is purely related to in situ observation.

The result "At times, imitation arose because of the movement that was carried out by some children", it was only perceived in two observations (Observations 1 and 2). It would be essential to have a greater number of observations in order to draw the attention to this data. In addition, it could be considered that the teacher could have had more attitudes directed towards drawing the attention of the children to pay attention to what the colleagues were doing (aspect that has been emphasized in this text).

\section{FINAL REMARKS}

The methodological proposal of relational psychomotricity was positively evaluated to be used by reference teachers in PE classes in schools located in outlying ghettos and in other suburbs. The reference teacher showed competence for the planning, execution and evaluation of the activities in Physical Education in the first years of Elementary Education, according to theoretical data.

The materials that were adapted to relational psychomotricity practices were appropriate, mainly considering children's social reality. Freire (2001) points out that "contents to be taught cannot be totally odd to the everyday routine" (p. 16). Therefore, throughout this intervention, students' productions were valued and used in the classes.

Although these materials were shown to be appropriate for the development of the classes, it is important to point out that this adaptation of materials for Physical Education classes occurred due to the social state in which the (public) school was located. It is defended the production of materials as a constituent element of the training of students, linked to the School's PoliticalPedagogical Project, to the theoretical indicators involved in pedagogical practice, not as a refuge for the lack of public investments in Education.

In the reality under study, it may be stated that this practice enabled imitation to emerge among children. One of the essential factors that triggered imitation was the fact that the teacher proposed playful activities and suggested children to imitate each other. Even though the main idea of this proposal was based on free activities, the teacher's interventions, i. e., proposal of activities, led to the emergence of imitation. 


\section{References}

Baquero, R. (1998). Vygotsky e a aprendizagem escolar (Vygotsky andschoollearning). Porto Alegre: Artes Médicas.

Bonnefond, Jean-Yves et al (2016). To institute conflictive cooperation on the quality of work. Educação, $v$. 39(esp), s42-s53. http://dx.doi.org/10.15448/1981-2582.2016.s.24326 [Accessed: September 21, 2018].

Brasil (2010). Resolução no 7, de 14 de dezembro de 2010. (Resolution no. 7, issued on December 14th, 2010). Brasília, DF: Diário Oficial [da] República Federativa do Brasil, 147, 239, Seção 1, 34-37.

Brasil. (2014). Lei de Diretrizes e Bases da Educação Nacional. (National Education Guidelines and Framework Law) (9th ed.). Brasília: Câmara dos Deputados, Edições Câmara.

Damiani, M. F. (2000). As “interações ensinantes” de professoras de sucesso: aprendizagem guiada e imitação. (Successful teachers' "learning interactions": guided learning and imitation). In 23 Reunião Anual da Anped, 2000. Reunião Anual da Associação Nacional de Pós-Graduação e Pesquisa em Educação. http://23reuniao.anped.org.br/trabtit2.htm\#gt13 [Accessed: September 21, 2018].

Damiani, M., Rochefort, R., Castro, R., Dariz, M., Pinheiro, S. (2013). Discutindo pesquisas do tipo intervenção pedagógica. (Discussing researches on pedagogical intervention). Cadernos de Educação, 45, 57-67.

https://periodicos.ufpel.edu.br/ojs2/index.php/caduc/article/view/3822 [Accessed: September 21, 2018].

Daniels, H. (2016). An activity theory analysis of learning in and for inter-school work. Educação, v. 39(esp), s24s31. http://dx.doi.org/10.15448/1981-2582.2016.s.24319 [Accessed: September 21, 2018].

Falkenbach, A. (2002). A Educação Física na escola (Physical Education in school). Lajeado: Univates.

Fernandes, V. (2007). Uma leitura sócio-histórica da imitação no processo de ensino e aprendizagem. (A sociohistorical reading of imitation in the teaching-learning process).In 30 Reunião anual da Associação Nacional de Pesquisa e Pós-Graduação em Educação. Retrieved from http://www.

http://30reuniao.anped.org.br/grupo_estudos/GE01-3527--Int.pdf. [Accessed: September 21, 2018].

Fonseca, D. G. (2015) Educação Física: para dentro e para além do movimento. (Physical Education: inside and beyond movement). Porto Alegre: Mediação.

Freire, P. (2001). Política e educação: ensaios. (Politicsand Education: essays) (5thed.). São Paulo: Cortez.

Furini, A., \& Selau, B. (2010). Psicomotricidade relacional e inclusão na escola. (Relational psychomotricity and inclusion in school). Lajeado: Univates.

Gondim, S. (2003). Grupos Focais como técnica de investigação qualitativa: desafios metodológicos. (Focus groups as a technique of qualitative investigation: methodological challenges). Paidéia, 12(24), 149-161. Retrieved from http://www.scielo.br/pdf/paideia/v12n24/04.pdf [Accessed: September 21, 2018].

González Rey, F.; Goulart, D. M.; Bezerra, M. S. (2016). Ação profissional e subjetividade: para além do conceito de intervenção profissional na psicologia. (Professional action and subjectivity: beyond the concept of professional intervention in psychology). Educação, 39(esp), s54-s65. http://dx.doi.org/10.15448/1981-2582.2016.s.24379 [Accessed: September 21, 2018].

Laitinen, A., Sannino, A., Engeström, Y. (2016). From controlled experiments to formative interventions in studies of agency: methodological considerations. Educação, 39(esp), s14-s23. http://dx.doi.org/10.15448/19812582.2016.s.24321 [Accessed: September 21, 2018].

Lakatos, E. M, \& Marconi, M. A. (2010). Fundamentos de metodologia científica. (Essentials Of Scientific Method) (7th ed.). São Paulo: Atlas.

Moraes, R. (2003). Uma tempestade de luz: a compreensão possibilitada pela análise textual discursiva. (A light storm: comprehension enabled by Discursive Textual Analysis). Ciência e Educação, 9(2), p. 191-211.

Negrine, A. (2002). O Corpo na Educação Infantil. (The body in early childhood Education).Caxias do Sul: Editora da Universidade de Caxias do Sul.

Oliveira, A. \& Basegio, I. (2016). A psicomotricidade relacional como possibilidade de intervenção com uma criança que apresenta autismo: um estudo de caso. (Relational psychomotricity as a possibility of intervention with a child with autism: a case study) http://www.anpedsul2016.ufpr.br/portal/wpcontent/uploads/2015/11/eixo22 ANI\%C3\%8A-COUTINHO-DE-OLIVEIRA-IVAN-ANT\%C3\%94NIO-BASEGIO.pdf [Accessed: September 21, 2018].

Stetsenko, A. (2016). Vygotsky's theory of method and philosophy of practice: implications for trans/formative methodology. Educação, 39 (esp), s32-s41. http://dx.doi.org/10.15448/1981-2582.2016.s.24385 [Accessed: September 21, 2018]. 
Vigotski, L. S. (2008). A brincadeira e o seu papel no desenvolvimento psíquico da criança. (Playtime and its role in the children mental development). Revista Virtual de Gestão de Iniciativas Sociais, 23-36.

Vygotski, L. S. (1993). Obras Escogidas (The Collected Works of L. S. Vygotski). Madrid: Visor, 1993. 